\title{
Advanced Ceramic Target Materials Produced by Self-Propagating High-Temperature Synthesis for Deposition of Functional Nanostructured Coatings - Part 2: Multicomponent Systems
}

\author{
Evgeny A. Levashov, Yury S. Pogozhev and Victoria V. Kurbatkina \\ National University of Science and Technology "MISIS", \\ Russia
}

\section{Introduction}

The introduction of doping elements $\mathrm{Al}$ and $\mathrm{Si}$ into the coatings allows one to attain a combination of the high characteristics of the hardness and wear resistance with a relatively low friction coefficient. One important factor in increasing of the durability of different products is the provision of thermal stability and oxidation resistance at high temperatures $[1,2]$. Therefore, the problem of the development of hard wear-resistant coatings with high thermal stability, heat resistance, and corrosion resistance is very urgent.

In this work, the possibility of synthesizing of promising composite materials based on $\mathrm{TiC}_{\mathrm{y}} \mathrm{N}_{\mathrm{z}}, \mathrm{Ti}_{5} \mathrm{Si}_{3}$, and $\mathrm{TiAl}_{3}$ from the reactionary mixtures in the Ti-Al- $\mathrm{Si}_{3} \mathrm{~N}_{4}-\mathrm{C}$ system is shown. As the initial components of the reactionary mixtures we used powders of titanium, aluminum, technical carbon (ash) of above-mentioned grades, and silicon nitride (TU 88-1143-88). The mixtures composition was determined from the accounting of the complete transformation of the initial reagents and the formation of the product with phase composition described by the general formula

$$
\mathrm{X} \times\left(\mathrm{TiAl}_{3}\right)+(100-\mathrm{X}) \times\left(0,448 \mathrm{TiC}_{0,5}+0,552\left(\mathrm{Ti}_{5} \mathrm{Si}_{3}+4 \mathrm{AlN}\right)\right),
$$

where $x$ is the mixture parameter taking values in the range from $10 \mathrm{up}$ to $50 \mathrm{wt} \%$.

The experimental compositions of the reactionary mixtures for the synthesis of the composite ceramic materials, depending on the mixture parameter, are presented in Table 1.

\begin{tabular}{|c|c|c|c|c|}
\hline \multirow{2}{*}{$\mathrm{x}, \mathrm{wt} \%$} & \multicolumn{4}{|c|}{ Content of the initial components in green mixture, wt \% } \\
\cline { 2 - 5 } & $\mathrm{Ti}$ & $\mathrm{Al}$ & $\mathrm{Si}_{3} \mathrm{~N}_{4}$ & $\mathrm{C}$ \\
\hline 10 & 63,9 & 17,3 & 14,3 & 4,5 \\
\hline 20 & 61,0 & 22,3 & 12,7 & 4,0 \\
\hline 28,1 & 58,6 & 26,4 & 11,4 & 3,6 \\
\hline 40 & 55,1 & 32,4 & 9,5 & 3,0 \\
\hline 50 & 52,1 & 37,5 & 7,9 & 2,5 \\
\hline
\end{tabular}

Table 1. Composition of the initial reaction mixtures in the Ti-Al- $\mathrm{Si}_{3} \mathrm{~N}_{4}-\mathrm{C}$ system 
The values of the adiabatic combustion temperature $\left(\mathrm{T}_{\mathrm{c}} \mathrm{ad}\right)$ of the reactionary mixtures in the $\mathrm{Ti}-\mathrm{Al}-\mathrm{Si}_{3} \mathrm{~N}_{4}-\mathrm{C}$ system and the equilibrium composition of the synthesis products at this temperature calculated using the "THERMO" software depending on the mixture parameter are listed in Table 2.

As the mixture parameter increases, the adiabatic combustion temperature decreases monotonically. In this case the content of ceramic phases (titanium carbide, nitride, and silicide) decreases and the fraction of metal melts increases. At $x=40$ and $50 \%$, phases of titanium aluminide and aluminum nitride appear. It should be noted that the equilibrium phase composition given in Table 2 shows the state of the system immediately after the combustion under the condition that the combustion temperature equals the adiabatic value. As the sample is cooled, the evolution of the microstructure and the phase composition of the product inevitably take place (the so-called secondary structure formation). For this reason, the composition of the final material should be differing. We can expect the mutual solubility of $\mathrm{TiC}$ and $\mathrm{TiN}$ with the formation of titanium carbonitride most probably, of the nonstoichiometric composition (taking into account the excess of titanium in the system).

\begin{tabular}{|c|c|c|c|c|c|c|c|c|c|}
\hline \multirow{2}{*}{$\begin{array}{c}\text { x } \\
\text { wt } \%\end{array}$} & \multirow{2}{*}{$\begin{array}{c}\mathrm{T}_{\mathrm{c}} \text { ad } \\
\mathrm{K}\end{array}$} & \multicolumn{6}{|c|}{ Calculated composition of final products at the adiabatic temperature, } \\
\cline { 3 - 10 } & & $\begin{array}{c}\mathrm{Al} \\
(\mathrm{l})\end{array}$ & $\begin{array}{c}\mathrm{TiC} \\
(\mathrm{s})\end{array}$ & $\begin{array}{c}\mathrm{TiN} \\
(\mathrm{s})\end{array}$ & $\begin{array}{c}\mathrm{Ti}_{5} \mathrm{Si}_{3} \\
(\mathrm{~s})\end{array}$ & $\begin{array}{c}\mathrm{Ti} \\
(\mathrm{l})\end{array}$ & $\begin{array}{c}\mathrm{Ti} \\
(\mathrm{s})\end{array}$ & $\begin{array}{c}\mathrm{TiAl} \\
(\mathrm{s})\end{array}$ & $\begin{array}{c}\mathrm{AlN} \\
(\mathrm{s})\end{array}$ \\
\hline 10 & 2309 & 17,3 & 22,5 & 25,3 & 33,1 & 1,8 & - & - & - \\
\hline 20 & 2046 & 22,3 & 20,0 & 22,5 & 29,4 & 5,9 & - & - & - \\
\hline 28,1 & 1863 & 26,4 & 18,0 & 20,2 & 26,4 & 9,0 & - & - & - \\
\hline 40 & 1733 & 24,6 & 15,0 & 11,0 & 22,0 & - & 9,04 & 14,5 & 3,8 \\
\hline 50 & 1732 & 19,6 & 12,5 & 2,7 & 18,0 & - & 3,5 & 36,3 & 7,4 \\
\hline
\end{tabular}

Table 2. Thermodynamical calculation of the adiabatic combustion temperature and the phase composition of the synthesis products at a specified temperature

From the results of a thermodynamic calculation, we can make an important conclusion that silicon nitride completely transforms during SHS. It decomposes onto the elements, which react with titanium forming the nitride and silicide phases. Since $\mathrm{Si}_{3} \mathrm{~N}_{4}$ is a refractory compound, this phase is often considered as inert additive not entering into any reactions. However, due to the higher chemical affinity of titanium with nitrogen and silicon, silicon nitride can be used as a reagent.

The experimental values of the combustion parameters for mixtures with $x=10 ; 20$ and $28,1 \%$ at the initial temperature equal to room temperature are presented in Table 3.

\begin{tabular}{|c|c|c|}
\hline $\begin{array}{c}\mathrm{x}, \\
\mathrm{wt} \%\end{array}$ & $\mathrm{~T}_{\mathrm{c}}, \mathrm{K}$ & $\mathrm{U}_{\mathrm{c}, \mathrm{cm} / \mathrm{s}}$ \\
\hline 10 & 1906 & 0,29 \\
\hline 20 & 1823 & 0,26 \\
\hline 28,1 & - & 0,25 \\
\hline
\end{tabular}

Table 3. Experimental values of the combustion temperature and rate at $\mathrm{T}_{0}=\mathrm{T}_{\text {room }}$ 
At initial room temperature and $x=10,20$, and $28.1 \%$, the combustion proceeds in the selfoscillation mode, while we failed to initiate the combustion at all at higher $\times(40$ and 50\%).

It is evident from Tables 2 and 3 that the experimental combustion temperature is lower than the calculated adiabatic temperature by $300-400 \mathrm{~K}$ on average, which is associated with heat losses for heating of the surrounding environment. It should be noted that, at $\mathrm{T}_{0}=293$ $\mathrm{K}\left(20^{\circ} \mathrm{C}\right)$, the sample with $\mathrm{x}=28.1 \%$ is incompletely combusted, so, it does not allow us to measure the combustion temperature.

The dependence of the combustion rate, measured by photodiode light indicator directly during the process of forced SHS pressing, from the composition of the initial reaction mixtures is shown in Fig. 1. It is seen that $U_{c}$ is almost invariable while the mixture parameter is varying in the range of $10-28.1 \%$. With further increase of the parameter X (40 and $50 \%$ ) the combustion rate decreases significantly.

The combustion rate of the three-layered briquettes under the conditions of the quasiisostatic compression is considerably higher than the combustion rate of homogeneous cylindrical samples in the reaction chamber. Obviously, that one of the causes of this phenomenon is the additional heat coming from the "chemical heater". We also cannot exclude the influence of the convective heat and mass transfer, which can intensify the heat transmission in the billet pores under the pressing conditions.

The results of an X-ray phase analysis of the compact synthesis products based on $\mathrm{TiC}_{\mathrm{y}} \mathrm{N}_{\mathrm{z}}$, $\mathrm{Ti}_{5} \mathrm{Si}_{3}$, and $\mathrm{TiAl}_{3}$ are presented in Table 4 . It can be seen that the phase composition and their quantitative ratio change when the mixture parameter is varied. For $x=10,20$, and $28.1 \%$, the predominant phase is titanium carbonitride $\mathrm{TiC}_{\mathrm{y}} \mathrm{N}_{\mathrm{z}}$, which is formed due to the chemical interaction between titanium, carbon and nitrogen, which is evolved during the decomposition of silicon nitride. As the mixture parameter increases, the $\mathrm{TiC}_{\mathrm{y}} \mathrm{N}_{\mathrm{z}}$ content in the synthesis products decreases from 55 to $48 \%$. In addition, we identified the phases of the intermetallic compound $\mathrm{TiAl}_{3}$ and titanium silicide $\mathrm{Ti}_{5} \mathrm{Si}_{3}$.

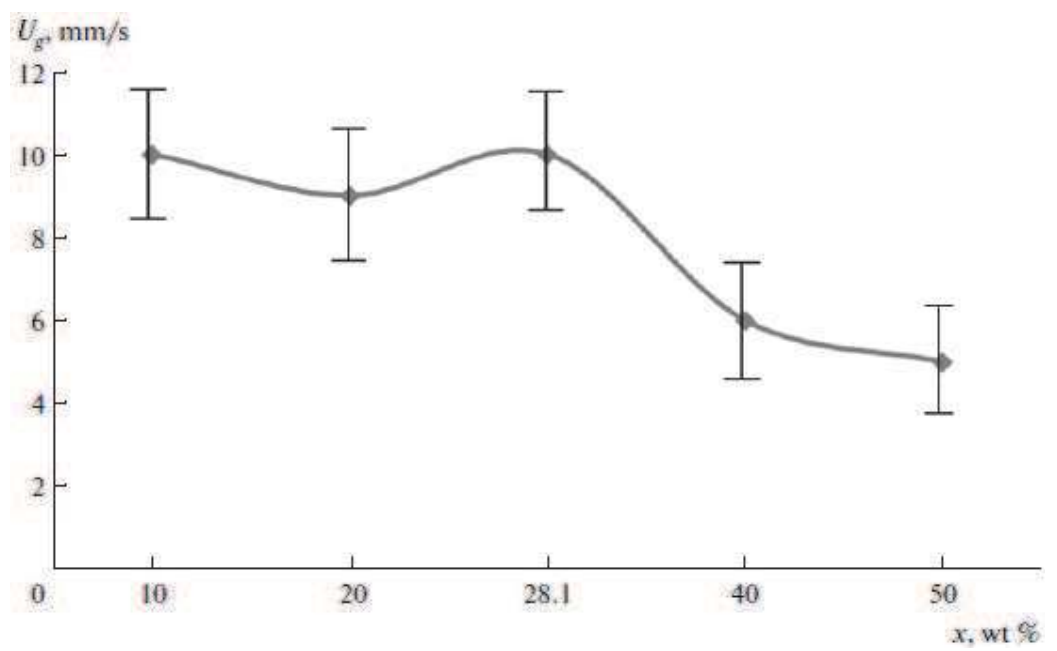

Fig. 1. Dependence of the combustion rate of the samples from the composition of the initial components during forced SHS pressing. 


\begin{tabular}{|c|c|c|c|c|c|c|c|c|c|c|}
\hline \multirow{3}{*}{$\begin{array}{c}\text { Phase in the } \\
\text { samples } \\
\text { composition }\end{array}$} & \multicolumn{10}{|c|}{ Mixture parameter $x$, wt $\%$} \\
\hline & \multicolumn{2}{|c|}{10} & \multicolumn{2}{|c|}{20} & \multicolumn{2}{|c|}{28,1} & \multicolumn{2}{|c|}{40} & \multicolumn{2}{|c|}{50} \\
\hline & $\begin{array}{c}\text { Fraction, } \\
\text { wt } \%\end{array}$ & $\begin{array}{l}\text { Period } \\
\mathrm{a}, \mathrm{nm}\end{array}$ & $\begin{array}{c}\text { Fraction, } \\
\text { wt } \%\end{array}$ & $\begin{array}{l}\text { Period } \\
\mathrm{a}, \mathrm{nm}\end{array}$ & $\begin{array}{c}\text { Fraction, } \\
\text { wt } \%\end{array}$ & $\begin{array}{l}\text { Period } \\
\mathrm{a}, \mathrm{nm}\end{array}$ & $\begin{array}{c}\text { Fraction, } \\
\text { wt } \%\end{array}$ & $\begin{array}{c}\text { Period } \\
\mathrm{a}, \mathrm{nm}\end{array}$ & \begin{tabular}{|c|} 
Fraction, \\
wt $\%$
\end{tabular} & $\begin{array}{c}\text { Period } \\
\text { a, nm }\end{array}$ \\
\hline $\mathrm{TiC}_{\mathrm{x}} \mathrm{N}_{\mathrm{y}}$ & 55 & $a=0,4285$ & 50 & $a=0,4284$ & 48 & $a=0,4286$ & 9 & $a=0,4270$ & - & - \\
\hline $\mathrm{TiAl}_{3}$ & 15 & $\begin{array}{l}a=0,3830 \\
c=0,8584\end{array}$ & 23 & $\begin{array}{l}a=0,3848 \\
c=0,8561\end{array}$ & 21 & $\begin{array}{l}a=0,3842 \\
c=0,8585\end{array}$ & 39 & $\begin{array}{l}a=0,3841 \\
c=0,8582\end{array}$ & 47 & $\begin{array}{l}a=0,3848 \\
c=0,8566\end{array}$ \\
\hline $\mathrm{Ti}_{5} \mathrm{Si}_{3}$ & 30 & $\begin{array}{l}a=0,7445 \\
c=0,5175\end{array}$ & 27 & $\begin{array}{l}a=0,7444 \\
c=0,5170\end{array}$ & 21 & $\begin{array}{l}a=0,7449 \\
c=0,5166\end{array}$ & 13 & $\begin{array}{l}a=0,7448 \\
c=0,5158\end{array}$ & 8 & $\begin{array}{l}a=0,7451 \\
c=0,5163\end{array}$ \\
\hline $\mathrm{Ti}_{3} \mathrm{SiC}_{2}$ & - & - & - & - & 10 & $\begin{array}{l}a=0,3074 \\
c=1,8144\end{array}$ & 39 & $\begin{array}{l}a=0,3043 \\
c=1,8117\end{array}$ & - & - \\
\hline $\mathrm{TiAl}_{2}$ & - & - & - & - & - & - & - & - & 29 & $\begin{array}{l}a=0,3971 \\
c=2,4289\end{array}$ \\
\hline$\beta-\mathrm{Si}_{3} \mathrm{~N}_{4}$ & - & - & - & - & - & - & - & - & 9 & $a=0,7765$ \\
\hline $\mathrm{TiC}$ & - & - & - & - & - & - & - & - & 7 & $a=0,4309$ \\
\hline
\end{tabular}

Table 4. Results of a quantitative phase analysis of the synthesized samples

At $\mathrm{x}=28.1 \%$, also the $\mathrm{Ti}_{3} \mathrm{SiC}_{2}$ phase presents in amounts to $10 \%$, while at $\mathrm{x}=40 \%$, its content increases up to $39 \%$. The phase composition of the products at $\mathrm{x}=40 \%$ also includes the $\mathrm{TiAl}_{3}$ intermetallic compound $(39 \%)$ and the $\mathrm{Ti}_{5} \mathrm{Si}_{3}$ and $\mathrm{TiC}_{\mathrm{y}} \mathrm{N}_{\mathrm{z}}$ phases $(13$ and $9 \%$, respectively).

The phase composition of the synthesis products with $x=50 \%$ has the strongest distinctions when compared with other samples under study. The presence of silicon nitride in almost the same amount as in the initial green mixture, as well as the $\mathrm{TiAl}_{2}$ intermetallic compound, indicates the incompleteness of the chemical reactions as a result of the incomplete combustion. The main phase is an intermetallide $\mathrm{TiAl}_{3}$ with a content of $47 \%$. In addition, a small amount of nonstoichiometric titanium carbide $(7 \%)$ with a lattice period of $0.4309 \mathrm{~nm}$ and titanium silicide $\mathrm{Ti}_{5} \mathrm{Si}_{3}(8 \%)$ are found.

Generalization of the data of an X-ray phase analysis allows us to conclude that increase in the mixture parameter from 10 to $50 \%$ lead to decrease in the content of the ceramic phases $\mathrm{TiC}_{\mathrm{y}} \mathrm{N}_{\mathrm{z}}$ and $\mathrm{Ti}_{5} \mathrm{Si}_{3}$ and to increase in the content of the metallic phase $\mathrm{TiAl}_{3}$.

Figure 2 shows the microstructures of the materials with various mixture parameters (magnification $\times 10000$ ). 

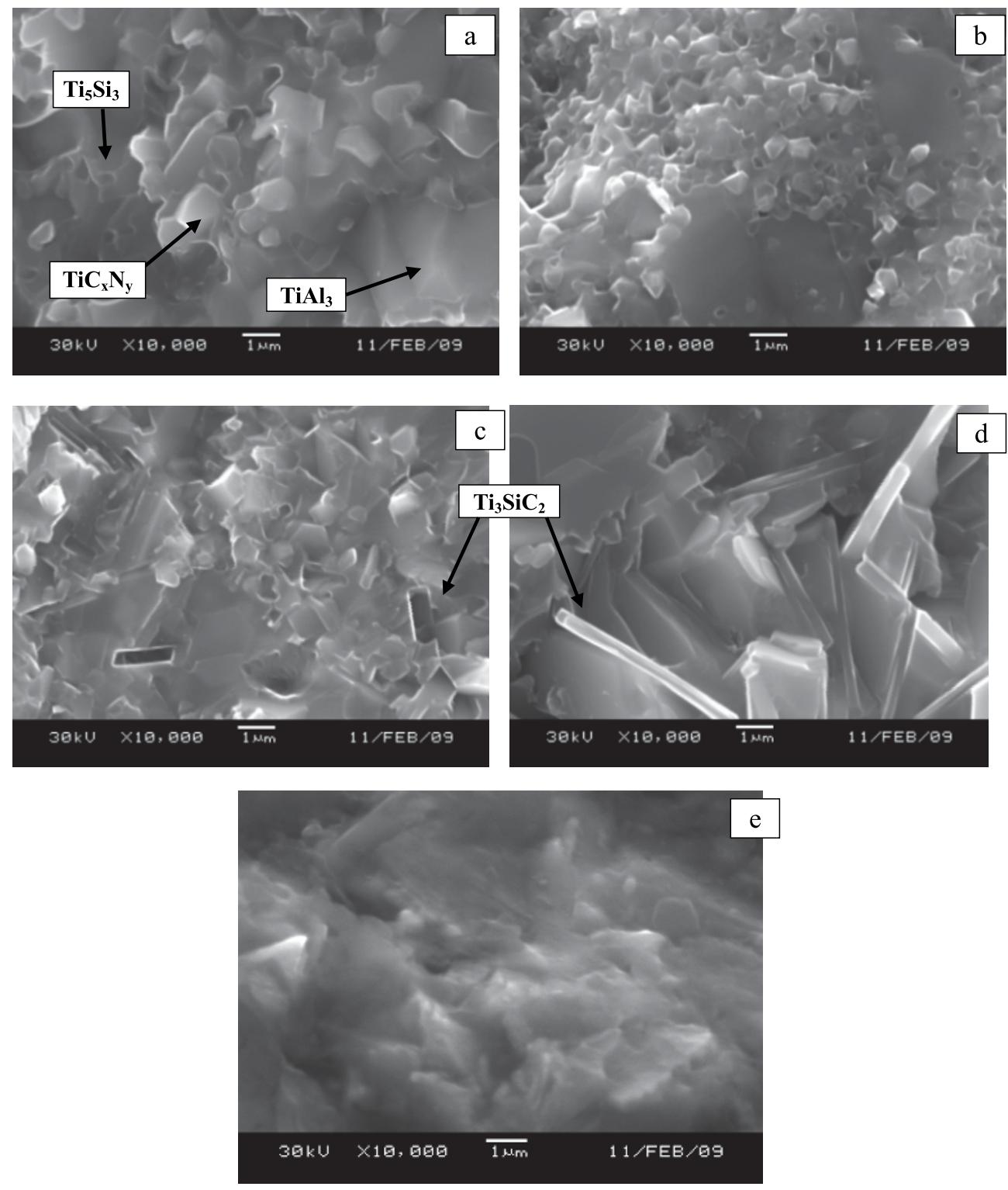

Fig. 2. Microstructures of the samples of compact ceramic materials based on $\mathrm{TiC}_{\mathrm{y}} \mathrm{N}_{\mathrm{z}}, \mathrm{Ti}_{5} \mathrm{Si}_{3}$, and $\mathrm{TiAl}_{3}$. x: = 10 (a); 20 (b); 28.1 (c); 40 (d); and 50 wt \% (e). 
At $x=10 \%$, the structure consists of titanium carbonitride grains (the average size of $\sim 1 \mu \mathrm{m}$ ) and $\mathrm{TiAl}_{3}$ and $\mathrm{Ti}_{5} \mathrm{Si}_{3}$ binder phases. As $\mathrm{x}$ increases from 10 to $20 \%$, the titanium carbonitride grains become finer to $0.5 \mu \mathrm{m}$. From a comparison of microstructures of the samples at $\mathrm{x}=$ 28.1 and $40 \%$ can be seen that, there is no changing in the grain size of $\mathrm{TiC}_{\mathrm{y}} \mathrm{N}_{\mathrm{z}}$ due to $\mathrm{x}$ increasing. In addition to titanium carbonitride, titanium aluminide and titanium silicide, the structure of this samples also contains the $M_{n+1} A X_{n}$ phase [3-5] of the $\mathrm{Ti}_{3} \mathrm{SiC}_{2}$ composition in the form of $\sim 300 \mathrm{~nm}$ thick characteristic layers. The phase interfaces in the sample with $x=50 \%$ are strongly spread, this is associated with the incompleteness of the chemical reactions during synthesis.

The physical and mechanical properties of the obtained materials, namely, the hardness, ultimate bending strength, and elasticity modulus, as well as the hydrostatic and true (measured using a helium pyknometer) densities, residual porosity, and ultrasonic rate in the bulk material, are given in Table 5 .

\begin{tabular}{|c|c|c|c|c|c|c|c|}
\hline$x$, wt $\%$ & $\begin{array}{l}\text { } \text { hydr., } \\
\mathrm{g} / \mathrm{cm}^{3}\end{array}$ & $\rho_{\mathrm{t}}, \mathrm{g} / \mathrm{cm}^{3}$ & $\mathrm{P}_{\text {res, }} \%$ & $\mathrm{C}, \mathrm{m} / \mathrm{s}$ & $\mathrm{HV}, \mathrm{GPa}$ & $\sigma_{\text {bend }}, \mathrm{MPa}$ & $\mathrm{E}, \mathrm{GPa}$ \\
\hline 10 & 4,19 & 4,34 & 3,7 & 6263 & 10,3 & 169 & 385 \\
\hline 20 & 4,18 & 4,27 & 2,3 & 5880 & 10,1 & 193 & 521 \\
\hline 28,1 & 4,04 & 4,06 & 0,5 & 6473 & 8,7 & 218 & 456 \\
\hline 40 & 3,76 & 3,82 & 1,6 & 5274 & 8,3 & 182 & 482 \\
\hline 50 & 3,18 & 3,67 & 13,4 & 4237 & 7,4 & - & - \\
\hline
\end{tabular}

Table 5. Physical and mechanical properties of ceramic materials based on $\mathrm{TiC}_{\mathrm{y}} \mathrm{N}_{\mathrm{z}}, \mathrm{Ti}_{5} \mathrm{Si}_{3}$, and $\mathrm{TiAl}_{3}$

At $x=50 \%$, the obtained material has an increased brittleness, so its strength properties were not measured.

It is evident from the measured data of the ultrasonic rate that the sample with the mixture parameter of $28.1 \%$ has fewer defects, while the highest defect concentration is observed for the composition with $x=50 \%$. These results completely agree with the characteristics of the residual porosity and strength. Since the residual porosity of the sample with $x=28.1 \%$ is $0.5 \%$, while for other compositions (excluding $x=50 \%$ ), it varies in the limits $2-4 \%$.

Based on the results of hardness measurement, we can see that, with increasing $\mathrm{X}$ from 10 to $50 \%$ the value of $\mathrm{HV}$ decreases from 10.3 to $7.4 \mathrm{GPa}$. This is associated with a decrease in the content of the hard carbonitride phase. The obtained values of hardness are fully comparable with the hardness of the carbide and nitride based ceramics, as well as of the classic hard alloys [6]. The sample with $x=28.1 \%$ has the highest strength. No direct dependence between the elasticity modulus, residual porosity, and mixture parameter is found.

The results of heat resistance tests for the materials based on $\mathrm{TiC}_{\mathrm{y}} \mathrm{N}_{\mathrm{z}}, \mathrm{Ti}_{5} \mathrm{Si}_{3}$, and $\mathrm{TiAl}_{3}$ are presented in Fig. 3. The values of their specific oxidation rate in air at $\mathrm{T}=1173 \mathrm{~K}$ and $\tau=30$ $\mathrm{h}$ are given in Table 6. 


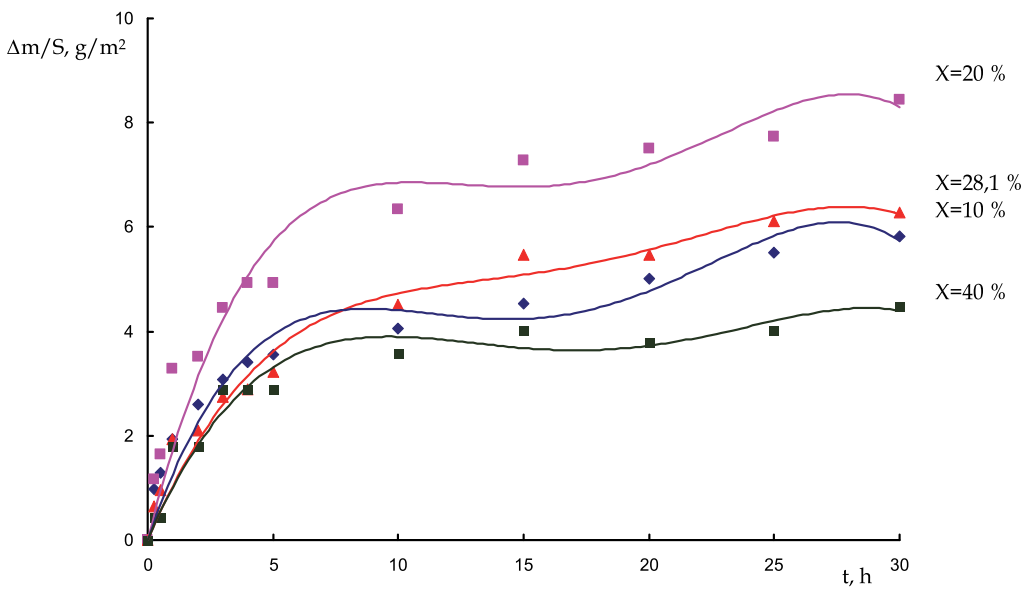

Fig. 3. Variation in the weight of the experimental samples of ceramic materials as a function of the oxidation time at $\mathrm{T}=1173 \mathrm{~K}$.

\begin{tabular}{|c|c|c|}
\hline $\mathrm{x}, \mathrm{wt} \%$ & Specific oxidation rate, $\mathrm{g} /\left(\mathrm{m}^{2} \times \mathrm{s}\right)$ & $\Delta \mathrm{m} / \mathrm{S}, \mathrm{g} / \mathrm{m}^{2}$ \\
\hline 10 & $5,4 \times 10^{-5}$ & 5,8 \\
\hline 20 & $7,8 \times 10^{-5}$ & 8,4 \\
\hline 28,1 & $5,8 \times 10^{-5}$ & 6,3 \\
\hline 40 & $4,1 \times 10^{-5}$ & 4,5 \\
\hline 50 & $1,6 \times 10^{-3}$ & 175,2 \\
\hline
\end{tabular}

Table 6. Specific oxidation rate of the samples of ceramic materials based on titanium carbide, titanium silicide, and titanium aluminide at $\mathrm{T}=1173 \mathrm{~K}$ for $\tau=30 \mathrm{~h}$

Oxidation process follows the parabolic law when the growth of the oxide film is limited by the diffusion of oxygen through the oxide layer. The material synthesized at $x=40 \%$ has the lowest oxidation rate $\left(4.1 \times 10^{-5} \mathrm{~g} /\left(\mathrm{m}^{2 \times} \mathrm{s}\right)\right)$, which is explained by a high content of highly heat resistant $\mathrm{TiAl}_{3}$ and $\mathrm{Ti}_{3} \mathrm{SiC}_{2}$ phases. It should be noted that oxidation rates of other samples in the system under study are very close to this best result, except for the sample with a mixture parameter of $50 \%$.

Developed ceramic materials based on titanium carbonitride, titanium silicide, and titanium aluminide (except material with $\mathrm{X}=50 \%$ ) were used for production by forced SHS pressing technology of experimental disc and segmented planar targets for ion-plasma deposition (magnetron sputtering) of multifunctional nanostructured coatings. The disk targets are shown in Fig. 4.

\section{Conclusions}

The modern views about the features of the synthesis of few interesting classes of the systems based on titanium carbonitride, silicide, aluminides, and $M_{n+1} A X_{n}$ phase are considered in this work. 


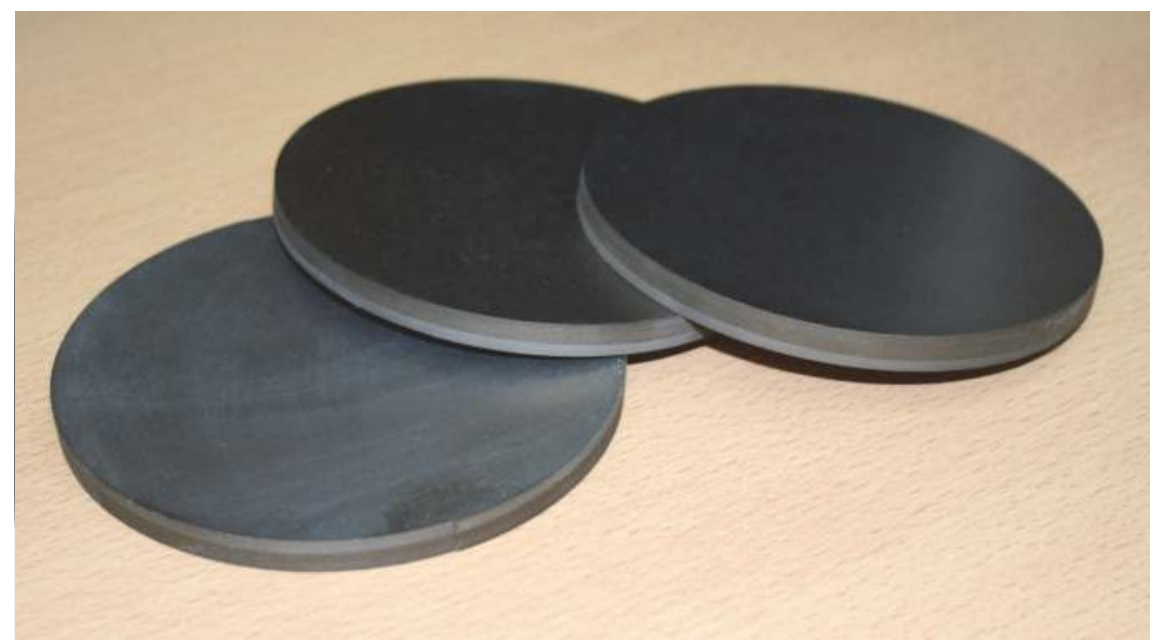

Fig. 4. Disc targets based on titanium carbonitride, titanium silicide, and titanium aluminide.

\section{Acknowledgment}

The experimental works described in the chapter were carried out due to financial support from the Federal Target Program "Scientific and scientific-and-pedagogical personnel of an innovative Russia" for 2009-2013 (State Contracts no. 02.740.11.0133, and 02.740.11.0859), as well as by the Program of creation and development of the National University of Science and Technology "MISIS".

\section{References}

[1] Shtansky, D.V., Kiryukhantsev-Korneev, Ph.V., Levashov, E.A., et al. (2007). Hard tribological Ti-Cr-B-N coatings with enhanced thermal stability, corrosion- and oxidation resistance. Surf. Coat. Technol., Vol. 202, p. 861.

[2] Kiryukhantsev-Korneev, Ph.V., Pierson, J.F., Levashov, E.A., et al. (2009). Effect of Nitrogen Partial Pressure on the Structure, Physical and Mechanical Properties of CrB2 and Cr-B-N films. Thin Solid Films, Vol. 517, p. 2675.

[3] Eklund, P., Beckers, M., Jansson, U., et al. (2010). The $M_{n+1} A X_{n}$ phases: Materials Science and Thin-Film Processing. Thin Solid Films, Vol. 518, p. 1851.

[4] Tzenov, N.V., Barsoum, M.W. (2000). Synthesis and Characterization of $\mathrm{Ti}_{3} \mathrm{AlC}_{2}$. J. Am. Ceram. Soc., Vol. 83, No. 4, p. 825.

[5] Levashov, E.A., Pogozhev, Yu.S., Shtanskii, D.V., Petrzhik, M.I. (2009). Self-propagating high-temperature synthesis of ceramic materials based on $M_{n+1} A X_{n}$-phases in TiCr-Al-C system. Rus. J. Non-Fer. Met., Vol. 50, No. 2, pp. 151-160.

[6] Panov, V.S., Chuvilin, A.M. (2001). Tekhnologiya i svoistva spechennykh tverdykh splavov i izdelii iz nikh (Technology and Properties of Sintered Hard Alloys and Articles on Their Base), MISiS, Moscow. 


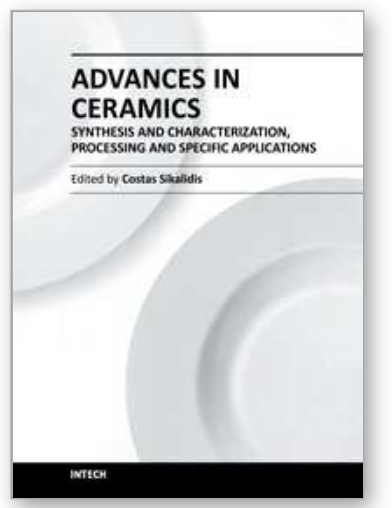

\author{
Advances in Ceramics - Synthesis and Characterization, \\ Processing and Specific Applications \\ Edited by Prof. Costas Sikalidis
}

ISBN 978-953-307-505-1

Hard cover, 520 pages

Publisher InTech

Published online 09, August, 2011

Published in print edition August, 2011

The current book contains twenty-two chapters and is divided into three sections. Section I consists of nine chapters which discuss synthesis through innovative as well as modified conventional techniques of certain advanced ceramics (e.g. target materials, high strength porous ceramics, optical and thermo-luminescent ceramics, ceramic powders and fibers) and their characterization using a combination of well known and advanced techniques. Section II is also composed of nine chapters, which are dealing with the aqueous processing of nitride ceramics, the shape and size optimization of ceramic components through design methodologies and manufacturing technologies, the sinterability and properties of $\mathrm{ZnNb}$ oxide ceramics, the grinding optimization, the redox behaviour of ceria based and related materials, the alloy reinforcement by ceramic particles addition, the sintering study through dihedral surface angle using AFM and the surface modification and properties induced by a laser beam in pressings of ceramic powders. Section III includes four chapters which are dealing with the deposition of ceramic powders for oxide fuel cells preparation, the perovskite type ceramics for solid fuel cells, the ceramics for laser applications and fabrication and the characterization and modeling of protonic ceramics.

\title{
How to reference
}

In order to correctly reference this scholarly work, feel free to copy and paste the following:

Evgeny A. Levashov, Yury S. Pogozhev and Victoria V. Kurbatkina (2011). Advanced Ceramic Target Materials Produced by Self-Propagating High-Temperature Synthesis for Deposition of Functional Nanostructured Coatings - Part 2: Multicomponent Systems, Advances in Ceramics - Synthesis and Characterization, Processing and Specific Applications, Prof. Costas Sikalidis (Ed.), ISBN: 978-953-307-505-1, InTech, Available from: http://www.intechopen.com/books/advances-in-ceramics-synthesis-and-characterization-processing-andspecific-applications/advanced-ceramic-target-materials-produced-by-self-propagating-high-temperaturesynthesis-for-depos 1

\section{INTECH}

open science | open minds

\section{InTech Europe}

University Campus STeP Ri

Slavka Krautzeka 83/A

51000 Rijeka, Croatia

Phone: +385 (51) 770447

\section{InTech China}

Unit 405, Office Block, Hotel Equatorial Shanghai

No.65, Yan An Road (West), Shanghai, 200040, China

中国上海市延安西路65号上海国际贵都大饭店办公楼 405 单元

Phone: +86-21-62489820 
Fax: +385 (51) 686166

Fax: +86-21-62489821

www.intechopen.com 
(C) 2011 The Author(s). Licensee IntechOpen. This chapter is distributed under the terms of the Creative Commons Attribution-NonCommercialShareAlike-3.0 License, which permits use, distribution and reproduction for non-commercial purposes, provided the original is properly cited and derivative works building on this content are distributed under the same license. 